\title{
Enhancing Direct Democracy: Case Studies in Vietnam
}

\author{
Yen Ha Thi Hai ${ }^{1, *}$ and Linh Nguyen Thi My ${ }^{1}$ \\ ${ }^{1}$ FPT University, Hanoi, Vietnam
}

\begin{abstract}
Direct democracy is the original and true way to ensure the power and position of the people as the owners of the state and society. Along with representative democracy, the implementation of direct democracy is important and indispensable in modern states in the world. In Vietnam, direct democracy has been recognized in many important legal documents and has been concerned by the Vietnamese Government, especially in recent times. Promoting and expanding direct democracy in Vietnam is evaluated as very correct and consistent actions of the Communist Party and the Government of Vietnam. The implementation of democracy is an important driving force to promote socio-economic development as well as people's sovereignty. It also stimulates the material and spiritual resources among the people to serve socio-economic development and fulfill social tasks. In the recent context of Vietnam, there are a lot of difficulties and challenges in implementing direct democracy, which requires significant solutions to strengthen in the future. In this paper, besides providing general research and opinions on direct democracy, the author focuses on analyzing issues of direct democracy implementation as well as proposing some solutions to improve direct democracy in Vietnam.
\end{abstract}

\section{Introduction}

Direct democracy is the original and accurate way to ensure the power and position of the people as the owners of the state and society; Along with representative democracy, the implementation of direct democracy is important and indispensable in contemporary political regimes. Through direct democracy, the people themselves could decide which laws and policies are important for the community and the country. In decades, the trend of strengthening direct democracy is increasingly stronger in all countries in the world.

Reality practices in the world show that there is no archetype for the application of direct democracy's forms in all countries in the world or for the different development stages of a country. Some forms of direct democracy are suitable for one society but they are not acceptable for the others. In other cases, the forms of direct democracy which bring good results for a society in a specific period may cause serious consequences for that society in another period. In order to successfully apply direct democracy, besides progressive and strict legal framework, parties, organizations and the citizens need to have an understanding of the nature of direct democracy as well as methods of enforcing direct democracy. They also have to be sensitive to the situation of their country, be dedicated to a true direct democracy and act based on the mutual benefits of the community and the nation.

Vietnam is a developing country and does not have a long history of democratic enforcement in general and direct democracy in particular. The main reason is that the constitutional foundation - the foundation for Vietnam's modern democratic mechanisms is quite new in comparison with other democratic regimes in the world (the first ever democratic regime of Vietnam only started on September 2, 1945 through the Declaration of Independence for the Democratic Republic of Viet Nam read by President Ho Chi Minh in Hanoi). Long-lasting fierce wars are additional factors affecting the effective organization and implementation of both direct democracy and representative democracy. In Vietnam recently, direct democracy is recorded in many important legal documents. The 2013 Constitution of the Socialist Republic of Vietnam, Law 96/2015/QH13 Law on Referendum, Law No. 85/2015/QH13 Law on Election of Deputies to the National Assembly and Deputies Deputies to People's Councils and Ordinance No. 34/2007/PLUBTVQH11 Ordinance on exercise of democracy in communes, wards and township are some of them. They provide clear definition, understanding as well as legal regulations about concepts, objects, general principles, procedures and validity of the results of direct democracy in Vietnam.

Accordingly, the system of state apparatus in Vietnam is demonstrated in Figure 1 bellowing.

\footnotetext{
*Corresponding author: YenHTH15@,fe.edu.vn
} 


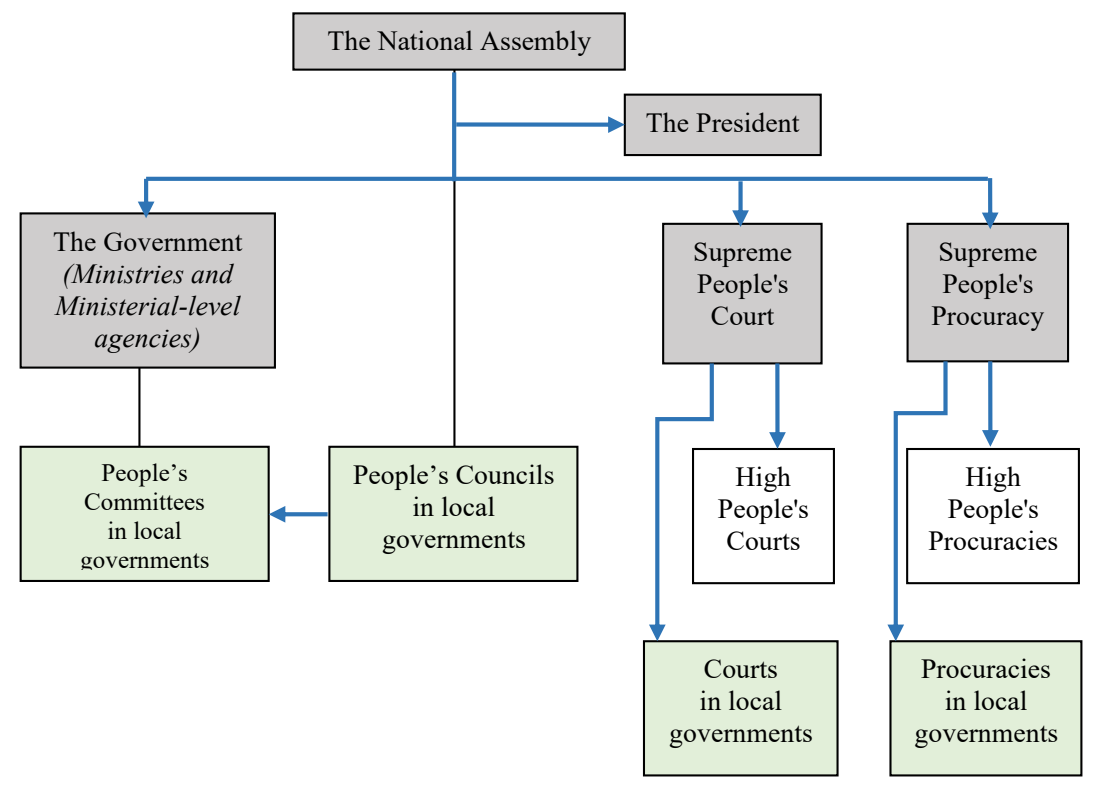

Fig 1. The system of state apparatus in Vietnam

Note: $\longrightarrow$ Elect the Head

At central level

At local level

The system of state apparatus in Vietnam has 2 levels. The central level includes The National Assembly, The President, The Government, Supreme People's Court and Supreme People's Procuracy. The local level includes agencies belonging to the legislative, executive and judicial powers: People's Councils in local governments, People's Committees in local governments, Courts in local governments and Procuracies in local governments.

The State of the Socialist Republic of Vietnam the country where the People are the masters. They elect representatives to the National Assembly and the People's Councils, which shall exercise legislative powers, under the principles of universal, equal, direct and secret suffrage (The 2013 Constitution of the Socialist Republic of Vietnam, Article 2; Article 6, Article 7 and Article 69). They are open to non-Party members and have the term of five years (Article 71).

The President of the State and the Prime Minister are elected by the National Assembly for a five-year term (Article 87 and Article 98). The President has the right to nominate candidates for a number of key positions including the Chief Justice of the Supreme People's Court and the Procurator-General of the People's Office of Supervision and Control. Nominees are then approved by the National Assembly.

The Government is the highest state administrative body of the Socialist Republic of Vietnam. It and People's Committees in local governments shall exercise executive power (Article 94). The Government is composed of the Prime Minister, Deputy Prime Ministers, Ministers, and Heads of ministerial-level agencies. The Prime Minister is the head of the Government and responsible to the National Assembly for the work of the Government and assigned tasks; and shall report on the work of the Government and the Prime Minister to the National Assembly, the Standing Committee of the National Assembly and the President.

The People's Courts are the judicial bodies of the Socialist Republic of Vietnam and exercise judicial power (Article 102) and the People's Procuracies shall exercise the power to prosecute and supervise judicial activities (Article 107).

Through the study about direct democracy in Vietnam, we are trying to solve the following questions:

- What is the current situation as well as difficulties and obstacles when implementing direct democracy in Vietnam?

- What are solutions to overcome existing difficulties and challenges?

Though the research's findings may not provide the most comprehensive solutions to overcome the recent problems of implementing direct democracy in Vietnam; the authors suppose that they detect major problems in Vietnam's direct democracy and give directions to solve them.

\section{Methodology}

Using a desk research approach (mainly from reports, presentations, learning materials from the PhD student training topics) and interview with three experts in the field of election and dismissal in Vietnam, the study seeks to gain indepth understanding of direct democracy in Vietnam and to evaluate its implementation in practice. 


\section{Literature review}

Direct democracy is understood as the form of people directly giving decisions on important matters of the nation and directly making laws without any intermediaries. The most popular forms of direct democracy include:

- Referendum is a direct vote in which all electorate is invited to vote to accept or veto a special proposal. It could be the adoption of a new Constitution, a set of laws, the dismissal of an elected official or simply a new government policy (Dao, Trinh, Vu, \& Truong, 2014; Truong, 2011; Dao, 2013).

- Voting is a process of making people's decisions to select an individual to hold government positions. This is the usual mechanism that democracies currently use to allocate positions mostly in the legislature branch and sometimes in the executive and judicial branches as well as in the local government (Central Committee of Vietnamese Fatherland Front, 2002; Shafritz, 1988; Nguyen, 2003).

- Recall election is understood as the electorate voting to express their mistrust with the elected representatives and force these representatives to retire their duties when their term was still available (The 2013 Constitution of the Socialist Republic of Vietnam, Article 7.2; The 1992 Constitution of the Socialist Republic of Vietnam, Article 7).

- Citizens' initiative is the act that citizens propose and vote to decide a matter of their country or local community. The condition for this implementation is that proponents must collect sufficient signatures on statutory initiatives range. Citizens' initiatives could be new proposals or proposals to amend existing legal documents or to decide important matters prescribed in the Constitution (Giao, n.d.).

- Grassroots democracy is understood as democracy at the lowest geographic or social level where people express their ownership most directly (Directive No 30-CT/TW; Ordinance No. 34/2007/PL-UBTVQH).

In the context of Vietnam, understanding and awareness about direct democracy and related matters come from some significant works of scholars around the world as following:

First of all is the handbook named Direct Democracy: The International IDEA Handbook (Beramendi, et al., 2008). It was translated and published in Vietnamese by the Institute of Public Policy and Law of VNU Publishing House in 2014 (Dao, Vu, Phung, Bui, \& Le, 2014). The handbook analyzes, compares and provides information and insights on the concerns related to direct democracy. Through the work, the authors articulate the perspective: Direct democracy demonstrates people's participation in government activities (Beramendi, et al., 2008). A range of democratic practices exists to help citizens become more and more involved in making political and institutional decisions. The handbook presents an overview of direct democracy implemented in all regions of the world and evaluates particular cases in 6 countries including Hungary, Switzerland, Uganda, United States (Oregon), Uruguay and Venezuela. The handbook also clarifies and examines the scope of usage four direct democracy mechanisms which are referendum, citizens' initiative, agenda initiatives and recall. Through case studies, the handbook provides a significant comparison among different direct democracy mechanisms and methods in which those mechanisms are applied in each country with specific contexts. Accordingly, this research partly reflects the practice of direct democracy in some countries around the world. This is a useful reference for researchers as well as the authors working on direct democracy implementation in Vietnam.

Besides the work of Beramendi, et al., it has to mention the contribution of David Held. Held's work shows in the book called Models of Democracy (Held, 2004) (its second and the third editions were published in 2006 and 2018 , respectively). In Vietnam, it was translated and published under the name Các mô hình quản lý nhà nuớc hiện đại which can be understood as Management models of modern states in English (Held, Pham, \& Đinh, 2013). The book consists of three parts, in which, in the first part, Held presents four classic democratic models including Athenian democracy - classical democracy, Republicanism, Liberal democracy and Direct democracy. In part two, he introduced four variants in the twentieth century and one is currently forming. In part three of the book, the author focuses on clarifying the question of "How should the democracy be understood today?". The author critically assessed the existing democratic models and thereby built up a definition of his own: democratic autonomy which is argued as "can link systematic difficulties that often occur and recur in political and social life" (Held, 2004). According to Held (2004), autonomy implies not only personal freedom and but also equal rights and responsibilities of individuals in organizing the community to ensure their eligibility to pursue their plans. This is a new contribution that sets the foundation for grassroots democracy in general and provides valuable suggestive topics for democracy research in the context of Vietnam.

Last but not least, the book called Le referendum: Etude Comparative of Francis Hamon (1995) was introduced to Vietnamese researchers and readers through the name Trung cầu dân ý: Một nghiên cúu so sánh. The book introduced the referendum, the relationship between democracy, democracy and the referendum (Hamon, 1995). According to Hamon (1995), democracy is understood in two different forms: the direct democracy (including the direct participation of each citizen in exercising political power) and the representative democracy (political power is entrusted to the elected representatives who take responsibility to the people). In his research, Hamon:

- Gives comprehensive theoretical and practical point view of referendum;

- Provides referendum models in some countries in the world. Those models include (i) scope and objectives of referendum; (ii) method of performing referendum; (iii) the relationship between referendum and political life; (iv) factors influencing the results of referendums; (v) the increase at global scale of referendums.

It can be said that this is an important reference for the authors to propose and apply for a referendum in Vietnam because there is no referendum which has been held since the Law on Referendum (2015) taking effect in July 2016. 


\section{Implementation of direct democracy in Vietnam}

In Vietnam, direct democracy implementation has received a lot of concerns and been gradually enhanced by the Government and citizens. Regardless of those actions, there are still many shortcomings.

First of all is the referendum. Initially, the Law on Referendum (2015) was created to create a legal mechanism for citizens to exercise their voting rights when the government bodies organize a referendum. However, in reality, since the Law has come into effect, no of referendum has been held. Considering the current legal documents, it can be seen that the law on referendum still has loophole and lacks detail causing difficulties in practice, specifically as follows:

(i) The issue of citizens' initiative: at first, it must have a citizens' initiative in order to conduct a referendum. The current Law on Referendum states that: "The Standing Committee of the National Assembly, the State President, the Government or at least a third of the total number of delegates of the National Assembly has the right to request the National Assembly to consider and make decisions on referendum." (Article 14, Law on Referendum, 2015). Citizens or voters do not have the right to propose referendums. Therefore, the absence of specific regulations on voters'/citizens' rights to request referendums has limited the practice of direct democracy.

(ii) The contradiction between Vietnam's current regulations on referendums and the nature of referendums: The 2013 Constitution stipulates that all State affairs are authorized to government bodies for example the National Assembly, the Standing Committee of the National Assembly, the State President and the Government. Therefore, in the case that a referendum is organized, the issue raised by the people directly to vote again falls under the deciding authority of the state agency. So far this contradiction has not been satisfactorily resolved.

(iii) The legal validity of the referendum results is unclear: The Law on Referendum 2015 states: "The Standing committee of the National Assembly shall be responsible for making a report to the National Assembly on the result of referendum in the next meeting session. Based on the result of the referendum, the National Assembly shall decide necessary measures to ensure the execution of the result." (Article 49, Law on Referendum 2015). This provision can be understood that the referendum's results will be reported to the National Assembly for consideration and the National Assembly has the right to accept or not accept such results. The decision of the National Assembly is final, and the will of the people expressed through the referendum is only for reference to government agencies. In this sense, the core of direct democracy - a form of helping people to decide for themselves important issues of the country, is not guaranteed to be implemented.

The second matter is the election. Currently, the voting has not fully promoted direct democracy in Vietnam. Some specific limitations can be seen as follows:

(i) Voters are lacking information about the candidates. Normally, the Election Boards make brief lists of information about the candidates to provide to the voters. However, the information in those lists of information is often very sketchy. Their contents include only name, hometown, workplace, education and position of the candidates, while the voters' most concerns, for example ability to work, morality, or their contribution for the society, are rarely provided.

According to the expert who is working at a faculty of Administrative Law in the southern of Vietnam, one of reasons for lacking information about candidates is that the electoral system in Vietnam is not ready for election campaigns in particular and competitive elections in general. The election campaigns in Vietnam recently are not actual election campaigns because there is no candidate competing with any others. With such rules and conception, it is not possible to mention election competitiveness as well as comprehensive access to information of candidates.

(ii) About equality of representation of voters. The Vietnamese law prescribes the principle of compulsory equality in elections. However, the equality of representation of voters in fact has not been ensured yet due to the unreasonable distribution of the number of elected representatives. In the recent National Assembly elections, there was a huge disparity in the proportions of the population of a province or a city and the number of National Assembly elected candidates. The three highest proportion belong to Ho Chi Minh City with 1 elected candidate representing for 234,838 people, Thanh Hoa with 1 elected candidate representing for 216,494, and Nghe An with 1 elected candidate representing for 218,879 people. Meanwhile, some provinces witness the significant low proportion of representation (around 5 times lower than the highest ones) such as Lai Chau with 1 elected candidate represent for 53,317 people, Bac Kan with 1 elected candidate represent for just 50,250 people (Resolution No. 53/NQ-HDBCQG).

Besides the above-mentioned matters, to understand more about the implementation of regulations related to election, the authors have some informal talks with two other experts who are prestigious researchers on state administrative law and especially democracy in Vietnam. The results of those talks as following:

According to an expert who is teaching at a department of State Administration Law in the northern of Vietnam, voters do not have adequate opportunities to select and nominate candidates for the National Assembly and the People's Councils. They have not played a decisive role in the election. He said that in a constituency which has 5 candidates to select 3 delegates, the opportunity for people to select their delegates is $40 \%$. The elected representatives are mainly due to "the structure"; the election becomes just a formality.

Another expert, who used to work in the system of state apparatus in Vietnam, mentions the right to dismiss beside election's matters. He said that the dismiss of delegates is as important as the election in terms of political and legal implications. If citizens have only the right to vote without the right to dismiss, the right to vote becomes just a formality.

From the practice of the election and the opinions of experts, it can be understood that strengthening direct democracy in Vietnam needs a lot of efforts to change recent regulations and notions from both lawmakers and voters. 
Thirdly, the matter of grassroots democracy. Ordinance No. 34/2007/PL-UBTVQH11 Ordinance on exercise of democracy in communes, wards and township has improved the legal basis for securing direct democracy at the grassroots level. According to statistics, up to $100 \%$ of communes, wards and towns have built and implemented grassroots democracy. However, the reality practice reflects that there are many documents at the grassroots level making their own regulations and policies without compliance with higher legal regulations, especially financial decisions (fees, charges, penalties, etc.). For example, in some communes of Gia Binh district, Bac Ninh province, the commune stipulates that villagers who have motor vehicles and agricultural vehicles must pay a specific amount of money per year as road maintenance fee. Outsiders with cars passing through the village must pay a fee from 3,000 to 4,000 VND per trip as road maintenance fee. In Thua Thien Hue, Ninh Thuan, Lang Son and Nghe An provinces, there is a regulation that people have to pay for processing documents and applications at the communes and wards. The fee reaches 20,000 VND or 30,000 VND per application (Quan, 2015).

\section{Solutions to enhance direct democracy in Vietnam}

Firstly, to complete and effectively implement the Law on Referendum in practice. The Law on Referendum has been in effect for 3 years, but in fact no referendum has been organized. In the future, it is necessary to amend the Law on Referendum in the directions that give voters the right to propose referendum initiatives and expand the scope of local referendums in order to ensure the voting right as well as nature and effectiveness of referendum when it is held in the State.

Secondly, to finalize the voter's rights as following:

- Issuing documents detailing provisions in the Law on Election of Deputies to the National Assembly and Deputies to People's Councils: (i) Guiding the process and procedures for voting at the workplace or permanent residence of the voter to ensure that voters could exercise their right under any circumstance. (ii) Guiding voters to register for voting at temporary residence instead of permanent residence.

- Ensuring the right to select the most competent candidates through the elimination of a restriction on the number of candidates per constituency.

- Prescribing sanctions for the case that one person cast other ballots. In some countries around the world such as Australia and New Zealand, the voting is a civic duty; if the citizens do not fulfill their duty, they can be subject to administrative sanctions. In Vietnam, voting is a citizen's right but the state also needs regulations to ensure voters exercise their right without affecting the exercise of the others' rights.

Thirdly, to strengthen grassroots democracy's regulations by promulgating the Grassroots Democracy Law on the basis of consolidating the current legal documents on grassroots democracy. This Grassroots Democracy Law should strengthen the implementation of democracy at the grassroots level, such as: (i) increasing the number of mattes that grassroots administrations must inform, discuss and absorb people's opinions; (ii) improving the legal effectiveness of receiving public comments; (iii) improving the people's supervision role in elected bodies in the localities.

\section{Conclusion}

Establishing a direct democracy is an indispensable development as well as an objective trend of mankind in order to ensure the principle that all state power belongs to the people. The implementation of democracy is an important driving force to promote socio-economic development and promote the people's ownership. In the process of social development towards sustainability and the creation of a constructive government, the leaders of the Vietnam Government are increasingly focusing on assessing the limitations and difficulties in implementing direct democracy. A specific roadmap to strengthen the implementation of direct democracy is essential in Vietnam currently. The authors hope that the research's theoretical contribution along with previous studies could help improve the effectiveness of direct democratic practices in Vietnam in the near future.

\section{References}

Beramendi, V., Ellis, A., Kaufmann, B., Kornblith, M., LeDuc, L., McGuire, P., Svensson, P. (2008). Direct democracy: The International Idea handbook. Stockholm: International IDEA.

Central Committee of Vietnamese Fatherland Front. (2002). Kỷ yếu công tác Mặt trận tham gia cuộc bầu củ đại biểu Quốc hội khóa XI, nhiệm kỳ 2002 - 2007 [Proceedings of the Front participated in the 11th National Assembly election, term 2002 - 2007].

Dao, T. U., Vu, C. G., Phung, P. T., Bui, H. T., \& Le, T. T. H. (2014). Dân chủ trục tiếp: Sổ tay Idea Quốc tế. Hanoi: VNU Publishing House.

Dao, T. U., Trinh, D. T., Vu, C. G., \& Truong, H. H. (2014). Some theoretical and practical issues on direct democracy and grassroots democracy in the world and in Vietnam. Hanoi: VNU Publishing House. 
Dao, U. T. (2013). Bản chất, nội dung và yêu cầu cơ bản của trưng cầu ý dân [The nature, content and basic requirements of the referendum]. In Proceeding of the Referendum Workshop - Theoretical and Practical Issues. Hanoi: The Vietnam Lawyers Association.

Directive No 30-CT/TW dated 18th December 1998 on the preparation and implementation of the regulation of democracy at grassroots level.

Hamon, F. (1995). Le referendum: Etude Comparative [Trung cầu dân ý: Một nghiên cúu so sánh]. Paris: L.G.D.J.

Held, D. (2004). Models of democracy. Cambridge: Polity Press.

Held, D., Pham N. T., \& Đinh, T. M. (2013). Các mô hình quản lý nhà nước hiện đại. Hanoi: Tri thức.

Giao, V. C. (n.d.). Dân chủ trực tiếp trên thế giới và nhũ̃ng gợi mở cho Việt Nam [Direct democracy in the world and suggestions for Vietnam]. Hanoi: Viet Nam Institute for Public Policy and Law.

Law No. 96/2015/QH13 on Referendum, 2015.

Law No. 85/2015/QH13 on Election of deputies to the National Assembly and People's Councils.

Nguyen, T. H. (2003). Hương ước mới - một phuơng tiện góp phần quản lýxã hội ở nông thôn Việt Nam hiện nay [New grassroots-level convention - a means to contribute to social management in rural Vietnam today]. Hanoi.

National Election Council (2016), Resolution No. 53/NQ-HDBCQG dated March 3, 2016 on the number of constituencies, list of constituencies and the number of National Assembly candidates to be elected in each constituency.

Ordinance No. 34/2007/PL-UBTVQH11 of the National Assembly Standing Committee on exercise of democracy in communes, wards and township.

Quan, M. (2015, August 25). "Lệ làng": Lắm khi hơn cả "phép vua" [Custom can sometimes rule the law]. Thanh Nien Newspaper.

Shafritz, J. M. (1988). The Dorsey dictionary of American government and politics. Chicago, IL: Dorsey Press.

The 2013 Constitution of the Socialist Republic of Vietnam.

The 1992 Constitution of the Socialist Republic of Vietnam.

Truong, H. T. H. (2011). Trung cầu ý dân: Nhũng vấn đề lý luận và thực tiễn [Referendum: Theoretical and practical issues]. Hanoi: Political - Administration Publishing House. 